\title{
The Comparison of the Ownership Structure at Different Level of the Financial Collapse in Listed Firms of Tehran Stock Exchange
}

\author{
*Saeid Jabbarzadeh Kangarlouei ${ }^{1}$, Vida Fattahi², Morteza Motavassel ${ }^{1}$ \\ ${ }^{1}$ Islamic Azad University, Orumieh Branch, Orumieh, Iran \\ ${ }^{2}$ Islamic Azad University, Tabriz Branch, Tabriz, Iran \\ *dr_jabbarzadeh@yahoo.com
}

\begin{abstract}
The main objective of this study is to compare ownership structure of different levels of collapse in listed companies of Tehran Stock Exchange (TSE). Study variables are the ownership structure that includes governmental ownership, private ownership (corporate ownership and individual ownership) and the different levels of collapse including latency stage, the stage of cash deficits and commercial and financial insolvency and complete collapse. Altman model ( $\mathrm{Z}^{\prime}$ - Score) is used to predict the collapse of firm and Chi-Square test is used to test the research hypothesis. The study is the applied research and statistical population of study includes 96 collapse firms that are active in the TSE (subject to Business Law Article 141). Given the availability of financial information of distressed companies in 7 years between 2004-2010 years, a sample of 81 members was selected. The results show that the ownership structure of collapsed firms is independent from their different levels of collapse.
\end{abstract}

Key words: Ownership structure, collapse firms and Tehran Stock Exchange.

\section{Introduction}

Recent big collapses all over the world and its implications on macro-economy world and the pressures have put on the accountants respecting their contributions on the financial crisis require that accounting scholars to be aware of their role in social events like bankruptcy. There is a question for accountants as to why accounting numbers are so doubtful. If accounting is to serve as economy facilitator why it is failed predicts recent crisis. Here is the case to all researchers to develop our filed by conducting the studies related to this world. Regarding this, in our contribution, we try to unfold one of these aspects. Financial decision-making is one of the most important subjects of financial management. The aim of providing financial and accounting information is to establish a base for economic and financial decision-making. All decision-makings need information which leads to selecting an efficient and effective resolution. Optimal and economic resolution selection requires compiling data, processing, and analyzing and logical inferences form information, which is called financial analysis in financial management literature. Analysis of financial statements helps shareholder and creditors in measuring whether as to firms are improving financially or in the future it will face constraint and bankruptcy (Rahnamaee et al, 2006).

One of the ways that helps in optimal utilizing of investment and better assignment of resources is predicting impending financial distress or bankruptcy. As such, firstly with providing necessary warnings it makes firm aware of impending financial distress to respect these warnings, necessary actions are taken. Secondly, investors and creditors can distinguish between favorable and unfavorable investment opportunities and invest their resources in favorable investment. On the other hand, nowadays there is a separation between ownership and control. By gradually decreasing direct governance of owners on firms, control is delegated to other groups such as board of directors and managers. Therefore, it is expected that every changes in ownership structure lead to changes in their strategic and performance and also increasing or decreasing agency cost (Mazloumi, 2005). Many researches have investigated the relationship between ownership structure and firm's performance and profitability. Considering that weak and improper performance and firm's consequent loss making may drive in financial distress, decision makers and investors should pay attention to firm's ownership structure in order to avoid from investment in firms with ownership structure likely to be financially distressed in order to mitigate risk. However, respecting to aforementioned issues, in this study the ownership structure at different level of financial distress in listed firms of TSE is explored. 


\section{Literature Review}

The subject of separation between ownership and management and its effect on organizations performance has been a matter of scrutiny for authors and researchers of organizational, industrial economic, financial and recently strategic management theories. In this regard, the top levels of organizational hierarchy, ownership structure (diversity and the level of ownership distribution), and effective procedures of management and corporate governance are the matters of researchers interest. Threshold to study this matter is to classify the types of ownership and control which is done in various way (Mazloumi, 2005). Nowadays there is a separation between ownership and control. By gradually decreasing direct governance of owners on firms, control is delegated to other groups such as board of directors and managers. Because of interrelationships and hierarchy between these groups, there rises an interaction between them which has two sides. First side is power interaction between them and the linkage methods of elements comprising this set which is called corporate governance. And this has implications on the firm's orientation and performance. Second side is that this interaction is established in the legal structure called corporation that using it burdens costs that called agency costs (Ibid). Considering aforementioned matters, it is expected that every changes in ownership structure leads to changes in the route of firm strategic and performance and also increasing or decreasing agency cost (Ibid).

On the other hand, recent financial distress of large international firms has caused that the matter of financial distress become an important issue in financial management. Bankruptcy is an objective subjects that firms struggle with, and because of its prevailing, it is also dominant matter in financial and investment literature as "ounce of prevention is better than a pound of cure". Exploring the roots of distress through the prevailing models is important. In fact, bankruptcy is the end of an entity activity. In this regard, understanding the roots of bankruptcy by financial management is dominant because firm's investors and managers are willing to be aware of bankruptcy to manage to prevent from it. Financial mangers may not recognize the bankruptcy signals to prevent firm from it unless they know the reasons that caused it (Rahnamaee et al., 2006). In economic view, financial distress can interpret as firm's loss making in which state firm is unsuccessful. In fact, in this state, firm`s return rate is less than cost of capital rate. Another form of financial distress is occurred when a firm fails to comply one or more articles of the debt contract such as holding current or equity to total assets ratio according to the contract which is called technical failure. Other states of failure are when firm's cash flows are insufficient for paying principal and interest of debt and also when the number of firms equity is negative (Raee \& Falahpour, 2008).

Fich \& Slezak (2007) investigated as to whether corporate governance saves distressed firms from bankruptcy. Their findings indicate that a distressed firm's governance characteristics significantly affect its probability of bankruptcy. They also found that smaller and more independent boards with a higher ratio of non-inside directors and with larger ownership stakes of inside directors are more effective at avoiding bankruptcy once distress is indicated. Their results were consistent with the belief that these types of governance structures induce more effective monitoring and also with the view that the inclusion of governance characteristics enhances the power of financial accounting models in predicting bankruptcy. Nahar (2006) examined the influence of board independence; CEO duality and ownership structure on the firm financial distressed status using a sample of distressed companies and a matchedpair sample of non-distressed companies listed on the Bursa Malaysia. He came to the end that board independence and CEO duality are not associated with financial distressed status and management and non-executive directors' interests are associated negatively with financial distress. He also documented a negative association for outside block holders. His evidence supports the contention that ownership by non-executive directors and outside block holders effectively increases their incentives to monitor management in ensuring their wealth in the firms is intact. Fan et al. (2009) explored regarding how institutional factors influence behavior of distressed firms. They discovered that institutional background matters considerably to distress resolution and distressed companies facing better institutional background (i.e. with less state ownership structure, in regions with better government quality and greater degree of local financial development), display relatively better operating performance, more disciplined capital structure, and higher ultimate recovery likelihood.

Chang (2009) examined about which corporate governance characteristics are correlated with financial distress by a sample of Taiwanese listed firms. He tested his Hypotheses by combining outside directors, CEO duality, and equity ownership by insiders, female directors, board size, multiple directorships, and 
director tenure. His results from logistic regression analysis show that board independence: boards with larger percentage of outside directors are less likely to fall into financial distress than boards with a lesser percentage. He also indicated that there is a positive correlation between board size and financial distress. Parker et al. (2002) investigated association of various corporate governance attributes and financial characteristics with the survival likelihood of distresses firms. Their results show that firms that replaced their CFO with an outsider were more than twice as likely to experience bankruptcy. Furthermore, they showed that larger level of block holders and insider ownership are positively associated with the likelihood of the firm survival. Charitou et al (2007) examined the earnings behavior of managers during the distressed period by looking at sources of abnormal accruals prior to the bankruptcy-filing year. Their results show that managers of highly distressed firms shift earnings downwards prior to the bankruptcy filing. They provided evidence in support of two potential contributing factors. First, top-level management turnover among distressed firm's leads new managers to earnings bath choices during the distressed period. Second, qualified audit opinions exert pressure on managers to follow more conservative earnings behavior during the distressed period. Their evidence is also provided that the management of distressed firms with lower (higher) institutional ownership has greater (lesser) tendency to manage earnings downwards. In addition, they highlighted that higher institutional ownership mitigates the negative abnormal returns of firms with top management turnover.

Elloumi \& Gueyie (2001) studied the relationships between corporate governance characteristics and financial distress status. They conclude that the board of director's composition explains financial distress, beyond an exclusive reliance on financial indicators. They indicated that outside directors' ownership and directorship affect the likelihood of financial distress. Tarraf (2011) find that aggressive risk taking, a corporate governance aspect, was a major cause of the 2007-2008 financial crises. He identifies three elements - improper incentive system, rationalization and opportunity - that encouraged managers in financial institutions to engage in aggressive risk taking. According to Business Law Article 142, if half of firm's equity eradicates because of incurred losses, board of directors must hold extraordinary general meeting immediately to decide on the firm`s going concern. If the meeting decides on existence, the firm equity must drop into the existence amount of equity.

Causes of Bankruptcy: It is not so easy to determine the causes of bankruptcy or financial distress precisely. Bankruptcy stems from several reasons together in so many cases. However, according to Dan and Bradstreet main causes of bankruptcy are financial and economic problems. Classifies the bankruptcy causes into two groups of internal and external organizational causes. According to external causes are (Rahnamaee et al., 2006): Economic system features, competition, changes in business and improvements and transitions in public demand, business validity, financing and incidents. According to Nyoton internal causes are which ones that can be prevented by firm's action. Most of these factors result from wrong decision-makings and its responsibility directed to firms. These factors are: extending excess credit, inefficient management, insufficient equity, conspiracy and fraud.

Bankruptcy Stages: classifies firm's unfavorable financial position into latency stage, the stage of cash deficits and commercial and financial insolvency and ultimately complete collapse. Although most of bankruptcies follow these stages, some of firms may bankrupt at once (Hajiha, 2005). With respect to mentioned theories and considering that the most of valid researches which state significant relationship between ownership structure, firm's performance and profitability, the relationship between ownership structure and financial distress is expected; however, we will try to answer the question that if firms ownership consists of different groups, which one of these combinations is significant at different level of firm`s financial distress. Although many researches have been conducted regarding ownership structure and its effect on performance, profitability and firm's value in worldwide, these researches are limited to the relationship between ownership structure, firm's performance and profitability. Taking into account that weak and improper performance and firm's continuous loss making can lead to financial distress, the relationship between ownership structure and financial distress is expected. By reviewing the databases and available resources it is found that there is no study regarding the subject of this research and most of these researches have studied ownership structure and financial distress with other variables independently. Below represents some of these researches: Despite many researches, there are no consensus about the relationship between ownership structure and its effect on firm's performance. Some researches show positive relationship between ownership structure and firm's performance and some others non-monotonous relationship. 
Corporate governance literature shows that equity and ownership structure affects firm's value, however, theories, on its own, can not predict this relationship explicitly and empirical results are inconsistent too (Margaritis \& Sillaki, 2009). Minguez et al. (2007) in a research titled "Does ownership structure affect value?" found a positive effect of ownership by main stock holders on firms value in the Spanish market which is not significant and regard ownership structure effects as a internal control mechanism in the capital market. They also argue that there may not be a systematic relationship between ownership structure and firm`s value. According to the results, considering main stockholders control, there is strong possibility of positive relationship between ownership and firms value (Minguez et al., 2007). Muhammadi and AlibafAsl (2009) investigated the concurrent and distinct role and effects of concentration and ownership structure on both firms return and value in TES. Their sample consists of 70 firms during the period of 2002 to 2007. Their findings show a liner and significant positive between concentration and firm's value. On the other hand, findings of ownership structure effect indicate, contrary to the negative relationship between stock return and governmental ownership ratio, there is a positive and significant relationship between individual, institutional, and private ownership and return. In addition, the results of investigating the relationship between ownership structure and firms value highlighted the same results. ShahSahebi (2000) studied the effect of influence, control and governmental and non-governmental ownership on firms return during the period of 1995-1999. Their results suggest that governmental ownership percentage is a neutral factor on governmental firms return. In other words, firms return does not change merely because of ownership transmission from government to nongovernment; rather firms return increasing needs a long term planning, control and monitoring on the dispossessed firm.

\section{Methodology}

This study is the applied research considering that the objective of this study is to help potential and present investors regarding optimal decision making in investing in corporations and accurate evaluation of financial statements items of investee. Moreover, it is descriptive study considering that it is aimed to compare ownership structure and financial distress in TSE. Research population consists of 96 firms of TSE informal window during the period of 2004-2010 that delisted according to Business Law Article 141. The sample is selected considering following conditions:

- Financial information especially notes of financial statements must be available for bankruptcy related calculations during the sample period.

- Sample firms must not be financial, investment institutions and banks.

- Documental and field methods are used to collect the data. The documental method is used for literature review and conceptual formwork (e.g. books, articles, theses, etc.). In the filed method, using TSE database and statistical technique, the relationship between ownership structure and financial distress in TSE is investigated and extended to the population of TSE.

Data analysis tool: After collecting the data, SPSS software is used to analyze it as following:

- Descriptive statistic: first the data is illustrated through descriptive statistic methods such as frequency tables, central parameters (mean, median, and mode) and dispersion parameters (variation, standard variation, etc.).

- Inferential statistic: considering that the measurement scale of research is nominal and ordinal, the Chi-Square test is used.

Research hypothesis: This research has one main hypothesis as following:

Distressed firms ownership structure is independent from the levels of financial distress.

Research Variables: The study variables are ownership structure at four sector of governmental and private (institutional and individual) and financial distress at three levels of latency stage, the stage of cash deficits and commercial and financial insolvency and complete collapse. We define each of variables as following (Muhammadi and AlibafAsl, 2009): Firm with governmental ownership: a firm that more than 50 percent of its stock belongs to government and or other governmental firms and sectors. Firm with institutional ownership: a firm that its biggest owner is a non-governmental legal entity. Firm with individual ownership: a firm that its biggest owner is individual entity. Firm with private ownership: a firm that its biggest owner is a non-governmental legal entity or individual entity (institutional ownership and individual ownership). 
Latency stage: In this stage firms may struggle with one or more unfavorable situation in conceal without immediately traceability such as demand declining. Economic losses often occur in this stage and assets return drops. The best disposition for firm is to discover the problem in this stage because easy resolutions those are effective in this stage will not work in next stages. In addition, if the problem is not solved in this stage, the public reliance will decrease.

Cash deficit: this position occurs when for first time a firm does not access cash to fulfill commitments (Rahnamaee et al., 2006).

Financial insolvency: in this stage, the firm has the ability to access to enough cash through consumptions channels and management has the ability of recognizing and solving the problem.

Complete insolvency: in this stage, total firm's debt is more than total assets and firm can not avoid from bankruptcy. Altman Z-Score Multiple Discrimination Analysis (MDA) is applied to financial distress likelihood prediction of sample firms, classifying them into four stages of latency, Cash deficit, commercial, and complete insolvency. The underlying reasons of selecting the Altman Z-Score are usage of Newton classification concerning firm's financial distress in the one hand and closeness of Nowton definitions of financial distress and Altman classification concerning the firm's financial distress likelihood on the other hand. In other words, none of the bankruptcy models is not be able to classify the financial distress into three level of very low, low and very high likelihood. Altman Z-Score is as following (RahnamaeeRoudposhti et al., 2006):

$\mathrm{Z}^{\prime}=0.717 \mathrm{x}_{1}+0.847 \mathrm{x}_{2}+3.107 \mathrm{x}_{3}+0.42 \mathrm{x}_{4}+0.998 \mathrm{x}_{5}$

$\mathrm{x}_{1}=$ working capital to total assets

$\mathrm{x}_{2}=$ retained income to total assets

$\mathrm{x}_{3}=$ earning before interest tax

$\mathrm{x}_{4}=$ book value of equity to book value of debt

$\mathrm{x}_{5}=$ total sale to total assets

The obtained number is described as following:

When $Z^{\prime}<1 / 33$, the possibility of bankruptcy is high,

When $1 / 33<Z^{\prime}<2 / 9$, firm is in bankruptcy reign,

When $Z^{\prime}>2 / 9$, the possibility of bankruptcy is low;

To analyze the data and to test the hypothesis using Chi-Square test, the relationship between two qualitative variables of ownership structure and financial distress levels is investigated.

\section{Results}

Descriptive Findings: In descriptive methods, the objective is to illustrate the research data through descriptive statistic tools such as central and dispersion parameters in order to make transparent the study subject.

Table 1: Descriptive statistic of governmental firms

\begin{tabular}{llllllll}
\hline \multicolumn{1}{c}{ Statistic } & $\mathbf{2 0 0 4}$ & $\mathbf{2 0 0 5}$ & $\mathbf{2 0 0 6}$ & $\mathbf{2 0 0 7}$ & $\mathbf{2 0 0 8}$ & $\mathbf{2 0 0 9}$ & $\mathbf{2 0 1 0}$ \\
\hline observations & 56 & 56 & 51 & 46 & 45 & 45 & 46 \\
mean & 1.484 & 0.758 & 0.120 & -1.866 & -1.860 & -2.725 & -4.989 \\
median & 1.697 & 1.559 & 1.542 & 0.723 & 0.475 & 0.217 & -0.143 \\
mode & -2.270 & -13.192 & -22.300 & -48.830 & -49.114 & -65.467 & -94.898 \\
range & 6.954 & 17.417 & 25.474 & 51.348 & 51.994 & 69.085 & 96.898 \\
Standard diviation & 1.519 & 2.877 & 4.039 & 9.108 & 8.544 & 1.503 & 1.617 \\
variation & 2.307 & 8.276 & 16.315 & 82.962 & 72.999 & 121.719 & 261.496 \\
skewness & -0.539 & -3.018 & -3.787 & -4.016 & -4.503 & -4.762 & -4.390 \\
kurtisis & 0.498 & 11.506 & 19.086 & 17.527 & 22.527 & 25.138 & 21.950 \\
min & -2.270 & -13.192 & -22.300 & -48.830 & -49.114 & -65.467 & -94.766 \\
max & 4.680 & 4.224 & 3.174 & 2.518 & 2.880 & 3.618 & 2.133 \\
Sum & 83.114 & 42.472 & 6.114 & -85.847 & -83.702 & -122.607 & -229.483 \\
\hline
\end{tabular}


Table 2: Descriptive statistic of private firms

\begin{tabular}{lrrrrrrr}
\hline \multicolumn{1}{c}{ Statistic } & $\mathbf{2 0 0 4}$ & $\mathbf{2 0 0 5}$ & $\mathbf{2 0 0 6}$ & $\mathbf{2 0 0 7}$ & $\mathbf{2 0 0 8}$ & $\mathbf{2 0 0 9}$ & $\mathbf{2 0 1 0}$ \\
\hline observations & 25 & 25 & 30 & 35 & 36 & 36 & $\mathbf{3 5}$ \\
mean & 0.992 & 1.257 & 1.009 & 0.575 & -0.121 & -0.372 & -1.080 \\
median & 1.310 & 1.287 & 0.937 & 1.000 & 0.654 & 0.149 & -0.046 \\
mode & -9.600 & -4.032 & -0.226 & -3.680 & -5.793 & -7.490 & -9.988 \\
range & 15.758 & 9.148 & 9.794 & 7.578 & 9.113 & 11.224 & 12.853 \\
Standard diviation & 2.766 & 1.886 & 1.887 & 1.659 & 2.188 & 2.277 & 2.993 \\
variation & 7.652 & 3.556 & 3.561 & 2.751 & 4.789 & 5.186 & 8.956 \\
skewness & -2.356 & -0.420 & -0.205 & -0.550 & -1.184 & -1.159 & -1.394 \\
kurtisis & 9.148 & 2.268 & 2.335 & 0.287 & 0.952 & 1.764 & 1.373 \\
min & -9.600 & -4.032 & -4.208 & -3.680 & -5.793 & -7.490 & -9.988 \\
max & 6.158 & 5.116 & 5.586 & 3.898 & 3.320 & 3.754 & 2.865 \\
sum & 24.802 & 31.427 & 30.255 & 20.111 & -4.352 & -13.392 & -37.804 \\
\hline
\end{tabular}

Table 3: Descriptive statistic of all firms (governmental and private firms)

\begin{tabular}{lrrrrrrr}
\hline \multicolumn{1}{c}{ Statistic } & $\mathbf{2 0 0 4}$ & $\mathbf{2 0 0 5}$ & $\mathbf{2 0 0 6}$ & $\mathbf{2 0 0 7}$ & $\mathbf{2 0 0 8}$ & $\mathbf{2 0 0 9}$ & $\mathbf{2 0 1 0}$ \\
\hline observations & 81 & 81 & 81 & 81 & 81 & 81 & 81 \\
Mean & 1.33 & 0.912 & 0.44 & -0.81 & -1.08 & -1.67 & 3.29 \\
median & 1.59 & 1.48 & 1.25 & 0.77 & 0.55 & 0.16 & -0.13 \\
Mode & -9.6 & -13.19 & 0.22 & -48.83 & 49.11 & -65.46 & -94.76 \\
Range & 15.7 & 18.308 & 27.88 & 52.72 & 52.43 & 69.22 & 97.63 \\
S. diviation & 1.98 & 2.60 & 3.41 & 7.02 & 6.55 & 8.40 & 1.24 \\
variation & 3.93 & 6.81 & 11.67 & 49.31 & 43.00 & 70.59 & 154.69 \\
skewness & -2.18 & -2.88 & -4.15 & -5.25 & -5.70 & -6.16 & -5.71 \\
kurtisis & 11.06 & 12.36 & 24.70 & 31.28 & 38.01 & 43.62 & 38.19 \\
Min & -9.60 & -13.19 & -22.3 & -48.83 & -49.11 & -65.46 & -94.76 \\
Max & 6.15 & 5.11 & 5.58 & 3.89 & 3.32 & 3.75 & 2.86 \\
Sum & 107.91 & 73.89 & 36.36 & -65.73 & -88.05 & -135.99 & -267.28 \\
\hline
\end{tabular}

The research hypothesis is examined during 7 years from 2004 to 2010 for each year separately. The null and alternative hypotheses are provided as following:

Null hypothesis: ownership structure of distressed firms is independent of the level of financial distress. Alternative hypothesis: ownership structure of distressed firms depends on the level of financial distress. The results of main hypothesis testing are summarized in table 3.

Considering the changes in firm's ownership structure during the study period, Chi-Square test is applied for each year separately. As it is shown in Table 4, taking the significance level (more than 5 percent) into account the null hypothesis is accepted. Therefore, two variables of ownership structure and the level of financial distress are independent. In other words, there is not difference between ownership structure and financial distress level.

Table 4: Chi-Square test results

\begin{tabular}{lllll}
\hline Year & $\alpha$ & sig & Sig & H0 \\
\hline 2004 & 0.05 & 0.468 & ? $<$ Sig & accepted \\
2005 & 0.05 & 0.843 & ? $<$ Sig & accepted \\
2006 & 0.05 & 0.181 & ? $<$ Sig & accepted \\
2007 & 0.05 & 0.106 & ? $<$ Sig & accepted \\
2008 & 0.05 & 0.151 & ? $<$ Sig & accepted \\
2009 & 0.05 & 0.86 & ? $<$ Sig & accepted \\
2010 & 0.05 & 0.544 & ? $<$ Sig & accepted \\
\hline
\end{tabular}

\section{Conclusion and Recommendations}

Research main hypothesis is investigated during the period of 2001-2007 for each year separately. The results show that ownership structure and level of financial distress are independent. In fact, different 
level of financial distress can not be explained by ownership structure. Regarding that the study is in the corporate governance world and it is not well-established in Iran (because this requires to complete denationalization and separation of management and ownership). However, ownership structure is in question in Iran because ownership structure is private in appearance while in fact it is governmental. Therefore, distinguishing firm's ownership structure is not possible.

Based on study, it is suggested to TSE and other related organizations such as auditing to classify and determine the level of financial distress and report the result to investors and other stockholders.

- Since the lion's share of country economy is in governmental sector. However, it is suggested that in the future studies the difference between managers behavior of private and governmental sector regarding firm's bankruptcy to be investigated.

- Since using listed firms of TSE endures some limitations for research on bankrupted firms. So using unlisted firms can help to improve the obtained results.

- Considering that the results of testing research hypothesis show independence of different ownership structure and financial distress. However, it is suggested that the impact of ownership structure on distressed firms to be investigated.

- Since Altman Z-Score is used in this research to test financial distress and considering the difference of preciseness of different methods of testing financial distress, it is suggested that other method of testing financial distress to be used in future studies.

- It is suggested that the research hypothesis to be investigated in different industries and based on firms characteristics.

\section{References}

Chang, C. (2009). The Corporate Governance Characteristics of Financially Distressed Firms: Evidence from Taiwan. The Journal of American Academy of Business, 15(1).

Charitou, A., Lambertides, N., Trigeorgis, L. (2007). Earnings Behavior of Financially Distressed Firms: The Role of Institutional Ownership. Abacus, 43(3).

Elloumi, F. \& Gueyie, G. (2001). Financial Distress and Corporate Governance. Corporate Governance, 1(1).

Fan, J., Huang, J. \& Zhu, N. (2009). Distress without Bankruptcy: An Emerging Market Perspective, http://ssrn.com/abstract=1360873.

Fich, E. \& Slezak, L. (2007). Can Corporate Governance Save Distressed Firms from Bankruptcy? An Empirical Analysis. Rev Quant Finan Acc, 30, 225-251, DOI 10.1007/s11156-007-0048-5.

Hajiha, Z. (2005). Firms Collapse- Causes and its Stages. Journal of Auditing, 29(3).

Mahdavi, A. \& Midari, A. (2005). Ownership Structure and Efficiency of Firms Listed in TSE. Economic Research, 71, 103-132.

Margaritis, D. \& Sillaki, M. (2009). Capital Structure, Equity Ownership and Firm Performance. Journal of Banking\& Finance, 34(3), 621-632.

Mazloumi, N. (2005). Relationship between Management Performance of Institutional Investors and Ownership Ratio of them in TSE. Quarterly journal of management studies, 47, 85-110.

Minguez, V. A. \& Francisco, M. U. J. (2007). Does Ownership Structure Affect Value? A Panel Data Analysis for the Spanish Market. Journal of International Review of Financial Analysis, 16, 81-98.

Muhammadi, S. H. \& AlibafAsl, M. (2009). Investigation of the Impact of Ownership Structure (central and combination) on Return and Firms Value Listed in TSE. financial research, 28, 69-69.

Nahar, A. S. (2006). Board Structure and Ownership in Malaysia: The Case of Distressed Listed Companies. Corporate Governance, 6(5), 582-594.

Parker, S., Peters, G. \& Turetsky, H. (2002). Corporate Governance and Corporate Failure: a Survival.

Raee, R. \& Falahpour, S. (2008). Application of Support Vector Machine in Financial Distress Prediction Using Financial Ratios. Accounting and Auditing Review, 53, 17-34.

Rahnamaee, R. F., Nikumaram, H. \& Shahverdianee, S. (2006). Strategic Financial Management.

ShahSahebi, S. (2001). Investigation of Ownership Structure on Stock Return in Listed Firms of TSE, M. A. thesis, Islamic Azad University, Science and Research Branch.

Tarraf, H. (2011). The role of corporate governance in the events leading up to the global financial crisis: analysis of aggressive risk-taking. Global journal of business research, 5(2). 